\title{
Different fertilization treatments in coal mining-affected soils change bacterial populations and enable soil reclamation
}

\author{
Yanzhuan $\mathrm{Cao}^{\dagger} \mathbb{D}$, Bingrui Zhou ${ }^{\dagger}$, Xiangying Wang, Huisheng Meng, Jian Zhang, Li Li and Jianping Hong*
}

\begin{abstract}
Purpose: Coal mining activities result in large-scale soil degradation and ecosystem imbalances in many countries. Fertilization is an effective way to improve soil fertility and microbial activity. However, the effect of different fertilizers and remediation time on the subsided soil is not clear. The aim of this study is to explore the effects on soil fertility and the bacterial community.
\end{abstract}

Methods: In this study, we compared three fertilization regimes (inorganic, organic, and combined) applied over a 5-year period for the purpose of rehabilitating subsoil through measurement of soil's chemical properties and microbial biomass. Bacterial diversity was evaluated in different reclaimed soils via high-throughput 165 rDNA sequencing; 1,938,561 total sequences were obtained.

Results: The results showed that fertilization improved various soil properties, including the concentrations of available phosphorus, available potassium, and alkali-hydrolysable nitrogen, therefore, increasing microbial biomass. A significant increase in soil microbial diversity was observed in fertilized soils compared to the initial conditions. A positive correlation between microbial diversity and soil properties was observed. Regarding an improvement in soil properties and crop yields, the organic fertilizer demonstrated significantly more effectiveness compared to the inorganic fertilizer. Meanwhile, the relative abundance of Proteobacteria, Bacteroidetes, and Verrucomicrobia increased, but the relative abundance of Chloroflexi and Nitrospirae decreased. More specifically, we found that several Proteobacteria subgroups, such as Rhizobiales, Myxococcales, Sphingomonadales, Rhodospirillales,

Xanthomonadales, and Burkholderiales, increased after the restoration. Additionally, the composition of the bacterial community in the 5-year groups (M5, O5, and MO5) was similar to the composition of the FS group, and the yield of the maize test crop following the 5-year restoration period was close to the average in China.

Conclusion: This result indicates that soil reclamation via fertilization can contribute to soil recovery over time. Therefore, we concluded that fertilization is an effective strategy for the restoration of soil properties and bacterial communities in mining soil.

Keywords: Mining area reclamation, Bacterial diversity, Chemical properties, 16S rDNA sequencing

\footnotetext{
* Correspondence: hongjpsx@163.com

†Yanzhuan Cao and Bingrui Zhou contributed equally to this work.

College of Resources and Environment, Shanxi Agricultural University, Taigu

030801, Shanxi, China
}

(c) The Author(s). 2020 Open Access This article is licensed under a Creative Commons Attribution 4.0 International License, which permits use, sharing, adaptation, distribution and reproduction in any medium or format, as long as you give appropriate credit to the original author(s) and the source, provide a link to the Creative Commons licence, and indicate if changes were made. The images or other third party material in this article are included in the article's Creative Commons licence, unless indicated otherwise in a credit line to the material. If material is not included in the article's Creative Commons licence and your intended use is not permitted by statutory regulation or exceeds the permitted use, you will need to obtain permission directly from the copyright holder. To view a copy of this licence, visit http://creativecommons.org/licenses/by/4.0/. 


\section{Introduction}

Soil bacteria are an essential component of ecological systems due to their role in carbon cycling via carbon fixation with photoautotrophic and chemoautotrophic microbes as well as organic carbon-consuming heterotrophic microorganisms (Trumbore 2006). Results from a previous study indicated that some soil bacteria promote nitrogen cycling through the conversion of ammonia to nitrite, which is utilized as their sole energy source (Kowalchuk and Stephen 2001). Falkowski et al. (2008) reported that soil microorganisms maintain a relatively stable set of core genes coding for the proteins of major redox reactions essential for life and biogeochemical cycles. In addition, soil microbes increase soil fertility, which improves soil structure, plant health, and crop production (Anderson, 2003; Czarnes et al. 2000; Song et al. 2007).

Since the demand for coal has been steadily increasing, coal mining activity has become more widespread. Underground coal mining causes large-scale land subsidence with subsequent soil erosion, surface disruption, and leveling measures that lead to loss of topsoil. Land subsidence and the associated re-leveling of affected land cause an imbalance in the soil ecosystem, resulting in a disruption of the microbial community and in reduced crop production. Numerous effects of subsidence in forest and agricultural lands have been reported worldwide, especially in India (Tripathi et al. 2009), Bangladesh (Hossain et al. 2015), and China (Yi et al. 2014). Thus, it is important to explore potential methods for the restoration of exposed subsoil and microbial diversity in subsided areas.

Previous studies have focused on the changes of microbial populations responding to land reclamation with parameters including the amount of available phosphorous (AP), available potassium (AK), soil microbial biomass carbon (MBC), and soil microbial biomass nitrogen (MBN) (Dimitriu et al. 2010; Anderson et al. 2008; Cui et al. 2012; Li et al. 2014a). However, the duration of reclamation was the only variable considered when exploring changes in microbial diversities in restored sites in these research projects. The most effective soil amendments for improving fertility and soil microbial status in subsided soils remains unclear. To explore the effects of different fertilizers and remediation time on soil fertility and the bacterial community, we studied the effects of different nutrient regimes after 1 year and 5 years of treatments. Microbial biomass and diversity, the variable soil properties $(\mathrm{pH}$, available phosphorus, available potassium, and alkali-hydrolyzable nitrogen), and crop yield were analyzed. Our study is of great significance not only to the local area, but also to the soil microbiome worldwide following land reclamation, crop tillage, and harvest assessment.

\section{Materials and methods Site description}

The study site covered $900 \mathrm{~m}^{2}$ of land affected by subsidence in the southeastern region of Shanxi Province, China $\left(36^{\circ} 28^{\prime} 11.95^{\prime \prime} \mathrm{N}, 113^{\circ} 00^{\prime} 52.57^{\prime \prime}\right.$ E). This area contains large areas of subsided land due to underground coal mining. The soil is described as calcareous cinnamon soil. Following the general reclamation measures of the area, the land was leveled to expose subsoil surface. The average elevation of this temperate-zone area is $970 \mathrm{~m}$, with a semi-humid, continental monsoon climate. The annual average temperature is $9.5^{\circ} \mathrm{C}$, annual frost-free period is 160 days, and annual rainfall is approximately $530 \mathrm{~mm}$.

\section{Soil treatments and vegetation}

To reuse the subsided land, the damaged area was gradually reclaimed since 2008 . The land was flattened by machinery firstly and then different fertilizers were applied. The reclaimed sites from the same geographic region had been fertilized for 1 and 5 years since 2012 and 2008, respectively. Three annual nutrient regimes were applied including (1) mineral fertilizer ( $\mathrm{M}$-containing urea (46\% nitrogen), superphosphate $\left(16 \% \mathrm{P}_{2} \mathrm{O}_{5}\right)$, and potassium chloride $\left.\left(60 \% \mathrm{~K}_{2} \mathrm{O}\right)\right)$; (2) organic fertilizer (O-composted chicken manure containing $26.7 \%$ organic matter, $1.68 \%$ nitrogen, $1.54 \% \mathrm{P}_{2} \mathrm{O}_{5}$, and $0.82 \%$ $\mathrm{K}_{2} \mathrm{O}$ ); and (3) a combination of inorganic and organic fertilizers (MO). To ensure that the different treatments provided similar nutrients, mineral fertilizers were applied at $1.757 \mathrm{t} \mathrm{ha}^{-1}$, organic fertilizers were applied at $12 \mathrm{t} \mathrm{ha}^{-1}$, and the combined treatment had $0.879 \mathrm{t} \mathrm{ha}^{-1}$ inorganic fertilizer and $6 \mathrm{t} \mathrm{ha}^{-1}$ organic fertilizer/plot. The fertilizers were mixed into the soil at a depth of 0 $15 \mathrm{~cm}$ after application. Maize was grown each year with a planting density of $52,500 \mathrm{ha}^{-1}$. The maize was sown in April and harvested in September of each year during the 5-year trial.

\section{Soil sampling}

All soil samples were collected from the experimental site in October 2013. Samples collected from the treatment plots after 1 year of treatment were labeled as CK1 (no fertilizer applied), M1, O1, and MO1. Samples collected after 5 years of treatments since 2008 were labeled as CK5 (no fertilizer applied), M5, O5, and MO5. The un-reclaimed soil (INI) and normal farmland soil (FS) were designated as the negative and positive controls, respectively. In addition, to reduce the inconsistency caused by other geological and environment factors, FS samples were collected nearby the subsided land, only $50 \mathrm{~m}$ away. A total of 30 individual soil samples (10 sites $\times 3$ replicates each) were analyzed. The samples were obtained from the top $0-20 \mathrm{~cm}$ layer using a $3-\mathrm{cm}$ - 
diameter auger. We collected multiple samples at each site and combined them into one soil sample. Each sample was divided into three parts: One part was prepared for microbial biomass carbon (MBC) measurement and stored at $4{ }^{\circ} \mathrm{C}$ for no more than $24 \mathrm{~h}$ before analysis; the second part was air dried and sieved for chemical analysis; the third part was stored at $-80{ }^{\circ} \mathrm{C}$ prior to DNA extraction.

\section{Measurement of soil chemical properties}

Soil pH was measured in a 1:1 soil-water mixture. Available phosphorus (AP) in each soil sample was extracted using sodium bicarbonate and measured via the colorimetric method described previously (Colwell 1963). Available potassium (AK) was extracted using ammonium acetate and measured by flame photometry (Cox et al. 1999). Alkali-hydrolysable nitrogen (AN) was also measured using the alkali-diffusion absorption method (Xiong et al. 2008). Soil MBC was determined using the chloroform fumigation-extraction method (Vance et al. 1987).

\section{DNA extraction and 165 rDNA sequencing}

Metagenomic DNA from $0.25 \mathrm{~g}$ soil samples was extracted using the PowerSoil DNA Isolation Kit (MOBIO Laboratories, USA). The quality and quantity of extracted DNA were evaluated by agarose gel electrophoresis and a NanoDrop 2000 spectrophotometer (Thermo Fisher Scientific, USA), respectively. Libraries were prepared to sequence the V3 region of $16 \mathrm{~S}$ rDNA, using modified Illumina $341 \mathrm{~F}$ and $518 \mathrm{R}$ primers (Muyzer et al. 1993), containing a 6-base barcode, and sequenced via the Illumina adapter sequence and Illumina sequencing primers, as described (Bartram et al. 2011), but with modifications. Briefly, $100 \mathrm{ng}$ of extracted DNA was used as the template for each amplification, and sequencing was performed in $50-\mu \mathrm{L}$ reaction mixtures. Each reaction mixture contained $0.3 \mu \mathrm{M}$ of each primer and $1 \times$ KAPA HiFi HotStart ReadyMix (Kapa Biosystems, Inc. Woburn, MA, USA), following the manufacturer's recommended protocol. A total of 18 cycles were completed in a thermocycler (Eppendorf, Germany). Amplified products of the correct size were recovered using a QIAquick Gel Extraction Kit (Qiagen, Germany) from $2 \%$ agarose gels. Recovered products were quantified using a Quant-iT PicoGreen dsDNA Kit (Life Technologies, Carlsbad, CA, USA) and a Qubit 2.0 Fluorometer (Life Technologies). Equal amounts of quantified products were pooled to generate the sequencing libraries. The pooled library was then sequenced using an Illumina MiSeq analyzer with the MiSeq Reagent Kit v2, 300-Cycles (Illumina, Inc., San Diego, CA, USA).

\section{Bioinformatics and statistical analyses}

Sequences were sorted by barcodes. Any reads with < $25 \%$ quality were removed from pyrosequencing-derived datasets using Trimmomatic software, version 0.30 . Then, the reads were assembled using mothur software, version 1.34.0 (http://www.mothur.org/), and assembled reads of $<400 \mathrm{bp}$ or $>480 \mathrm{bp}$ were removed. Operational taxonomic units (OTUs) of the sequences were determined using QIIME (http://qiime.org/tutorials/otu_ picking.html) with a similarity threshold of $97 \%$. The OTUs were used to evaluate the diversity of the microbial communities. The sequences were taxonomically classified using an RDP Bayesian classifier at a confidence level of $97 \%$. Diversity indices and community richness were determined using the Chao 1 estimator and the Shannon index, and rarefaction curves were determined using mothur software, version 1.34.0.

Differences in the AK, AP, $\mathrm{AN}, \mathrm{pH}$, and $\mathrm{MBC}$ resulting from the experimental treatments were examined by one-way analysis of variance with Duncan's post hoc test. Two-way analysis was also performed using the fertilization treatments and treatment time as main effects with Tukey's multiple comparison test. Statistical significance was set at $p<0.05$. Correlations between soil fertility parameters and microbial diversity indices were conducted using Pearson's correlation analysis. Data analysis was performed using SPSS software version 22.0 and GraphPad Prism software version 5.01 (Wang et al. 2016).

\section{Results}

\section{Soil properties and maize yields}

To compare the effect of different fertilizations to the subsided soil, the soil properties of different groups were analyzed (Table 1). The observed soil $\mathrm{pH}$ ranged from 7.93 to 8.08. In general, the $\mathrm{AP}, \mathrm{AK}, \mathrm{AN}$, and $\mathrm{MBC}$ levels were significantly higher in all treatment groups (M1, O1, MO1, M5, O5, and MO5) than in the negative control INI $(p<0.05)$ while the AP, AN, and MBC levels in all treatment groups were significantly lower than those in the positive control FS group $(p<0.05)$, indicating that fertilization plays a role in the improvement of soil chemical properties after reclamation. Despite the improvements fertilization can provide, it still cannot achieve the same effect of the normal farmland soil (FS).

To investigate the different treatment's effects over the years, the data collected from 1-year (CK1, M1, O1, and MO1) and 5-year reclamation groups (CK5, M5, O5, and MO5) were compared (Table S1). The fertility parameters and maize yields in fertilizer treatment groups were significantly higher than those in CK groups, and the 5-year fertilizer treatment groups showed a significant increase compared to the 1-year groups $(p<0.05)$, while no significant changes of AP, AK, and AN were 
Table 1 Soil properties and maize yields at each experimental site

\begin{tabular}{|c|c|c|c|c|c|c|}
\hline Sample no. & $\mathrm{pH}$ & AP (mg/kg) & AK (mg/kg) & AN $(\mathrm{mg} / \mathrm{kg})$ & $\mathrm{MBC}(\mathrm{mg} / \mathrm{kg})$ & Maize yield (kg/ha) \\
\hline $\mathrm{INI}$ & $8.06 \pm 0.09^{a}$ & $3.18 \pm 0.18^{f}$ & $48.51 \pm 2.69^{f}$ & $1.70 \pm 0.25^{f}$ & $5.39 \pm 1.04^{h}$ & - \\
\hline CK1 & $7.97 \pm 0.11^{\mathrm{ab}}$ & $4.36 \pm 1.15^{f}$ & $151.22 \pm 7.13^{\mathrm{de}}$ & $19.43 \pm 1.57^{\mathrm{e}}$ & $35.39 \pm 0.93^{9}$ & $1793.50 \pm 92.41^{f}$ \\
\hline M1 & $8.01 \pm 0.02^{\mathrm{ab}}$ & $7.85 \pm 0.35^{\mathrm{e}}$ & $162.25 \pm 3.98^{c d}$ & $28.44 \pm 1.03^{\mathrm{cd}}$ & $50.74 \pm 1.39^{f}$ & $2793.50 \pm 103.32^{\mathrm{e}}$ \\
\hline O1 & $8.02 \pm 0.02^{\mathrm{ab}}$ & $12.40 \pm 1.35^{d}$ & $173.15 \pm 3.15^{b c}$ & $25.89 \pm 0.55^{d}$ & $71.56 \pm 6.65^{\mathrm{e}}$ & $3566.50 \pm 157.62^{d}$ \\
\hline MO1 & $8.08 \pm 0.02^{\mathrm{a}}$ & $11.38 \pm 1.50^{d}$ & $181.44 \pm 2.60^{b}$ & $31.44 \pm 1.97^{c}$ & $57.81 \pm 6.51^{f}$ & $3652.50 \pm 134.61^{d}$ \\
\hline CK5 & $7.93 \pm 0.04^{b}$ & $4.88 \pm 0.66^{f}$ & $141.90 \pm 5.42^{\mathrm{e}}$ & $20.01 \pm 2.39^{e}$ & $52.06 \pm 6.06^{f}$ & $2460.17 \pm 433.60^{\mathrm{e}}$ \\
\hline M5 & $7.94 \pm 0.06^{\mathrm{ab}}$ & $20.53 \pm 1.53^{c}$ & $199.93 \pm 13.82^{\mathrm{a}}$ & $37.46 \pm 2.03^{b}$ & $152.60 \pm 8.85^{d}$ & $5352.68 \pm 121.41^{c}$ \\
\hline O5 & $8.02 \pm 0.11^{\mathrm{ab}}$ & $28.78 \pm 2.95^{b}$ & $201.97 \pm 8.42^{\mathrm{a}}$ & $37.38 \pm 3.41^{b}$ & $191.43 \pm 8.73^{b}$ & $6378.19 \pm 160.78^{b}$ \\
\hline MO5 & $7.93 \pm 0.10^{b}$ & $29.36 \pm 2.11^{b}$ & $204.57 \pm 14.34^{\mathrm{a}}$ & $38.68 \pm 2.27^{b}$ & $174.80 \pm 7.25^{c}$ & $6341.50 \pm 104.14^{b}$ \\
\hline FS & $7.98 \pm 0.02^{a b}$ & $36.42 \pm 0.65^{a}$ & $208.37 \pm 1.04^{\mathrm{a}}$ & $48.59 \pm 4.04^{a}$ & $225.84 \pm 4.22^{\mathrm{a}}$ & $8776.60 \pm 345.18^{a}$ \\
\hline Year (A) & * & $* * *$ & $* * *$ & $* * *$ & $* * *$ & $* *$ \\
\hline Fertilization (B) & NS & $* * *$ & NS & * & $* * *$ & $* *$ \\
\hline$A \times B$ & NS & NS & NS & NS & NS & NS \\
\hline
\end{tabular}

Data represent the means $\pm \mathrm{SE} ; n=3$; values followed by different letters are considered significantly different $(p<0.05)$ according to Duncan's multiple comparison test. Significance for two-way ANOVA with reclaimed year and fertilization. NS not significant $(p<0.05)$. ${ }^{*} p<0.05$ significance. ${ }^{* *} p<0.01$ significance. ${ }^{* * *} p<0.001$ significance. AP available phosphorus, $A K$ available potassium, $A N$ alkali-hydrolyzable nitrogen, $M B C$ microbial biomass carbon. INI initial soil without treatment, CK1 and CK5 no fertilizer for 1 and 5 years, respectively, M1 and M5 1 year and 5 years of mineral fertilizer, O1 and O5 1 year and 5 years of organic fertilizer, MO1 and MO5 1 year and 5 years of combined of inorganic and organic fertilization, FS normal farmland soil without land subsidence

observed between CK1 and CK5, indicating an improvement in rehabilitation of soil nutrients with fertilization over the years. Comparing the data from the mineral fertilizer $(\mathrm{M})$, organic fertilizer $(\mathrm{O})$, and combined organic and inorganic fertilizer (MO), the results showed that after 1-year of reclamation, the contents of AP and the maize yields for MO1 and O1 treatments were significantly higher than those of M1 treatment $(p<0.05)$. The $\mathrm{O} 1$ treatment had higher content of MBC than the $\mathrm{M} 1$ and MO1 treatment. After the 5-year reclamation, the contents of $\mathrm{AP}, \mathrm{MBC}$, and the maize yields in the $\mathrm{O} 5$ and MO5 groups were significantly higher $(p<0.05)$ compared to the M5 group. There were no significant differences in $\mathrm{pH}, \mathrm{AN}$, or $\mathrm{AK}$ between the three fertilizer treatments. The results indicated that organic fertilization (either alone or combined with inorganic fertilizer) was more effective than inorganic fertilization in improving soil properties and crop yields.

Moreover, as revealed by two-way analysis of variance (Table 1), both treatment time (A) and fertilization (B) have a significant effect on soil AP, AN, MBC, and maize yield $(p<0.01$ or $p<0.001)$. In addition, treatment time had a significant effect on soil $\mathrm{pH}$ and $\mathrm{AK}(p<0.05$ or $p$ $<0.001)$. There were not any interactive effects between treatment time (A) and fertilization (B).

Effect of reclamation treatment on soil bacterial diversity To investigate the impact of different fertilizers on bacterial populations, a total of 1,938,561 sequences were obtained in this study. Shannon rarefaction curves were generated using Shannon diversity indices to compare the diversity of the bacterial community in different treatments. As shown in Fig. S1, all curves reached a plateau, which indicates that sequence-derived diversity was sufficient to characterize microbial species. In addition, the Shannon indices of treatment groups were significantly increased compared to the initial sample (INI) $(p<0.05$; Table 2). There was no significant difference among the six treatment groups $(p>0.05)$.

The alpha diversity (Shannon, Chao 1, and ACE) indices in the INI samples were the lowest and were significantly different from treatment groups and FS $(p<0.05$; Table 2). The Shannon indices of all treatment groups and the Chao 1 and ACE values of organic fertilizer treatment were not significantly different compared to the positive control FS group (Table 2). Two-way ANOVA tests revealed that fertilization (B) but not treatment time (A) had significant effects on the Chao1 and ACE indices in the reclamation sites (Table 2) while no significant difference in the Shannon index was found between treatment time (A) and fertilization (B), indicating that fertilization reclamation (especially organic fertilizer) had positive effects on soil microorganisms.

\section{Bacterial community compositions}

To further understand the diversity of the soil microbial community, we performed pyrosequencing to distinguish 10 groups of bacteria at the phylum level (Fig. 1). As shown in Fig. 1a, the mean abundances of the dominant populations across all treatments were Proteobacteria (32.7\%), Actinobacteria (24.3\%), Bacteroidetes (7.1\%), Acidobacteria (6.7\%), Chloroflexi (6.4\%), Gemmatimonadetes (5.9\%), and Firmicutes (2.1\%). Different taxa, however, were observed at the phylum level across different 
Table 2 Richness and diversity indices for all samples

\begin{tabular}{llll}
\hline Sample no. & Shannon & Chao1 & ACE \\
\hline INI & $10.23 \pm 0.63^{\mathrm{c}}$ & $5027.79 \pm 1041.01^{\mathrm{e}}$ & $5259.43 \pm 1136.53^{\mathrm{e}}$ \\
CK1 & $11.10 \pm 0.13^{\mathrm{ab}}$ & $9176.42 \pm 1153.96^{\mathrm{d}}$ & $9566.54 \pm 1252.53^{\mathrm{d}}$ \\
M1 & $11.10 \pm 0.14^{\mathrm{ab}}$ & $9801.86 \pm 1446.67^{\mathrm{cd}}$ & $10496.67 \pm 1540.66^{\mathrm{cd}}$ \\
O1 & $11.24 \pm 0.11^{\mathrm{ab}}$ & $11185.28 \pm 545.56^{\mathrm{abc}}$ & $12037.12 \pm 345.87^{\mathrm{abc}}$ \\
MO1 & $11.05 \pm 0.16^{\mathrm{ab}}$ & $11857.49 \pm 1114.83^{\mathrm{ab}}$ & $12757.53 \pm 31243.65^{\mathrm{ab}}$ \\
CK5 & $10.87 \pm 0.80^{\mathrm{b}}$ & $10400.77 \pm 357.57^{\mathrm{bcd}}$ & $10979.09 \pm 341.81^{\mathrm{bcd}}$ \\
M5 & $11.28 \pm 0.08^{\mathrm{ab}}$ & $10398.70 \pm 711.47^{\mathrm{bcd}}$ & $11152.10 \pm 681.42^{\mathrm{bcd}}$ \\
O5 & $11.33 \pm 0.08^{\mathrm{ab}}$ & $11686.81 \pm 832.46^{\mathrm{ab}}$ & $12437.37 \pm 923.35^{\mathrm{ab}}$ \\
MO5 & $11.12 \pm 0.30^{\mathrm{ab}}$ & $10208.80 \pm 1206.51^{\mathrm{bcd}}$ & $10893.57 \pm 1314.10^{\mathrm{bcd}}$ \\
FS & $11.67 \pm 0.04^{\mathrm{a}}$ & $12530.26 \pm 143.91^{\mathrm{a}}$ & $13361.16 \pm 155.45^{\mathrm{a}}$ \\
Year (A) & NS & $*$ & NS \\
Fertilization (B) & NS & NS & $*$ \\
AxB & NS & NS
\end{tabular}

Data represent the means $\pm \mathrm{SE}, n=3$, values followed by different letters are considered significantly different $(p<0.05)$ according to Duncan' $\mathrm{s}$ multiple comparison test. Significance for two-way ANOVA with reclaimed year and fertilization. NS not significant $(p>0.05) .{ }^{*} p<0.05$ significance. INI initial soil without treatment, CK1 and CK5 no fertilizer for 1 and 5 years, respectively, M1 and M5, 1 year and 5 years of mineral fertilizer, 01 and 051 year and 5 years of organic fertilizer, MO1 and MO5, 1 year and 5 years of combined of inorganic and organic fertilization, FS normal farmland soil without land subsidence

soil samples (Fig. 1b). The combined abundance of Actinobacteria and Proteobacteria in the control group (INI) was $36.5 \%$, while it was $>55 \%$ in all treated groups. The relative abundances of Chloroflexi, GAL15, Nitrospirae, and Euryarchaeota in the INI group were significantly higher than other groups $(p<0.05)$, and there was no significant difference found between treatments and FS groups. The relative abundances of Proteobacteria and Bacteroidetes in the INI group were significantly lower than other groups $(p<0.05)$. In addition, there was no significant difference observed for the relative abundances of Gemmatimonadetes and Planctomycetes

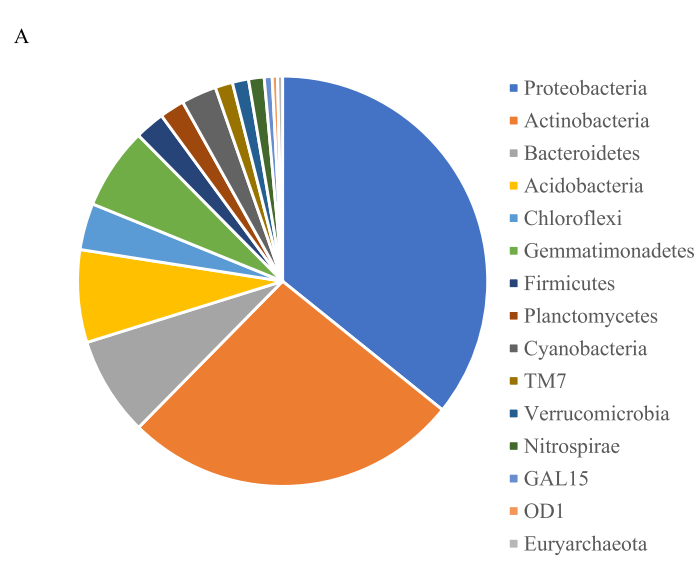

B
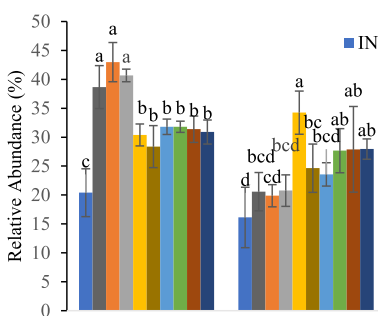

Proteobacteria

Actinobacteria

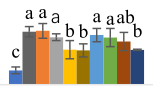

Bacteroidetes
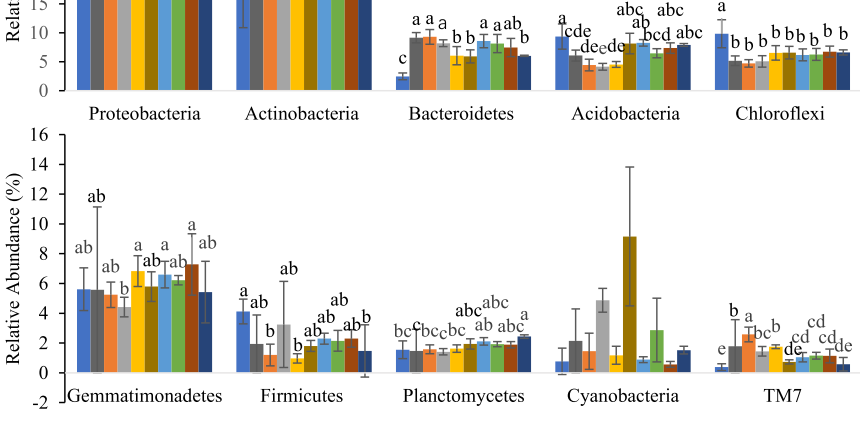

Chloroflex
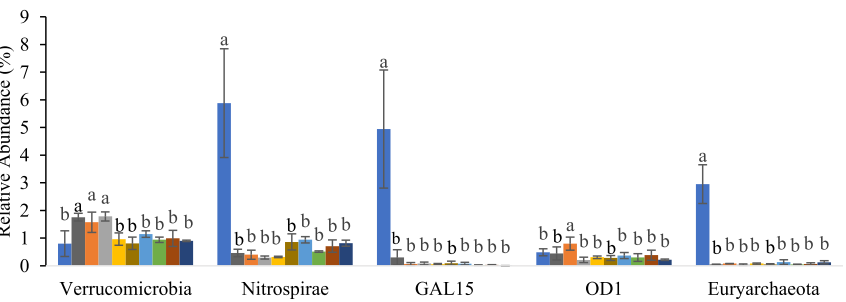

Fig. 1 The relative abundances of the 15 most prevalent bacteria at the phylum level in all samples combined (a) and in each treatment (b) Values followed by different letters are considered significantly different $(p<0.05)$ according to Duncan's multiple comparison test 
between the treatments and INI groups. Furthermore, the bacterial community compositions in the treatment of M5, O5, MO5 were more similar to those in the FS group, indicating that soil reclamation with fertilization may take some time to recover the microbial community structure.

The difference of bacteria structure among different treatments was compared (Table S2). The abundance of Proteobacteria, Actinobacteria, Bacteroidetes, TM7, and Verrucomicrobia in MO1 was significantly different to that of M1 $(p<0.05)$. The abundance of Acidobacteria, Nitrospirae, and Euryarchaeota in M5 was significantly higher than that of O5. In addition, the abundance of Proteobacteria and Verrucomicrobia of the 1-year fertilization group was significantly higher than that of the 5-year group, while the abundance of Acidobacteria and Nitrospirae was the opposite. The results indicated that fertilization treatment and reclamation time were both driving factors for soil microbial restoration.

\section{Bacterial community structures}

To investigate the organization of the bacterial community, a heat map showing hierarchical clustering was generated. The relative abundances of the top 40 bacteria ( $Y$-axis) were assessed at the order level across different treatments ( $X$-axis) (Fig. 2). There was an increase in the most orders observed in the reclamation site compared to INI. The top 10 orders of the treatment groups included Actinomycetales, Rhizobiales, Myxococcales, Sphingomonadales, Xanthomonadales, iii1-15, Bacteroidales, Solirubrobacterales, Rhodospirillales, Acidimicrobiales, and Burkholderiales. Actinomycetes were the most predominant order and increased significantly after reclamation $(p<0.05)$. The greatest abundance of Actinomycetes was in the treatment of MO1(24.09\%), which was significantly higher than that of CKl $(13.87 \%, p<$ 0.05). In addition, 6 of the top 10 orders belonged to the phylum Proteobacteria and all increased in abundance after reclamation (Table 3). The bacterial community structures in the fertilizer treatment of the 5-year groups (M5, O5, and MO5) and FS group clustered together, showing similarities in the bacterial community structures between them. The results implied that the time of reclamation was an important factor for soil microbial remediation

To further investigate the bacterial community variation, a principal coordinate analysis ( $\mathrm{PCoA}$ ) was implemented in all samples (Fig. 3). The first and second principal components accounted for $22.46 \%$ and $16.54 \%$ of the variance, respectively. The profile of microbial communities in INI and the 1-year group (except MO1) was separate from those in MO1, the 5-year group and FS along PCoA 1 . In contrast, PCoA 2 showed that bacterial communities in 1-year group were separated from

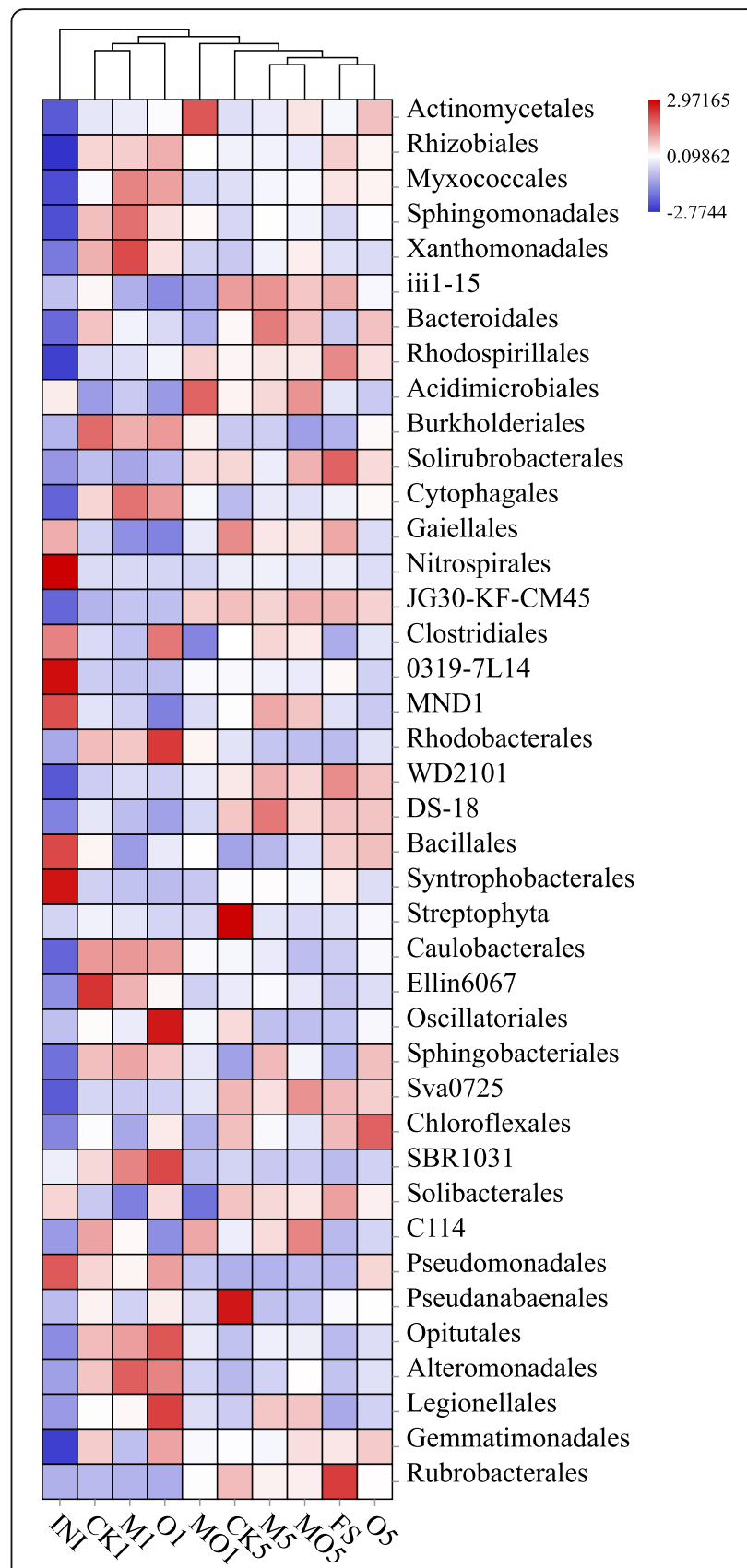

Fig. 2 A hierarchal clustered heatmap showed bacterial distributions at the order level in soils after different reclamation treatments

others. Bacterial community profiles in the 5-year reclaimed sites (CK5, M5, O5, and MO5) and FS formed a cluster in quadrant II, separate in the 1-year reclaimed sites (CK1, M1, O1, and MO1) in quadrant III and IV. Collectively, these results suggested that the composition and richness of bacterial communities changed after reclamation and the community compositions in the 5-year treatment groups exhibited similar features to the FS group. 
Table 3 Relative abundance of phylogenetic order under the Phylum of Proteobacteria at each experimental site (relative abundance $>1 \%)$

\begin{tabular}{|c|c|c|c|c|c|c|c|c|c|c|}
\hline \multirow[t]{2}{*}{ Order } & \multirow[b]{2}{*}{ INI } & \multicolumn{7}{|c|}{ Samples(\%) } & \multirow[b]{2}{*}{ MO5 } & \multirow[b]{2}{*}{ FS } \\
\hline & & CK1 & M1 & 01 & MO1 & CK5 & M5 & O5 & & \\
\hline Rhizobiales & $1.86^{\mathrm{b}}$ & $5.74^{\mathrm{a}}$ & $5.83^{\mathrm{a}}$ & $6.22^{\mathrm{a}}$ & $5.16^{\mathrm{a}}$ & $4.95^{\mathrm{a}}$ & $4.97^{\mathrm{a}}$ & $5.32^{\mathrm{a}}$ & $4.82^{\mathrm{a}}$ & $5.82^{\mathrm{a}}$ \\
\hline Myxococcales & $2.16^{\mathrm{b}}$ & $4.45^{\mathrm{a}}$ & $5.84^{\mathrm{a}}$ & $5.53^{\mathrm{a}}$ & $3.97^{\mathrm{a}}$ & $4.08^{\mathrm{a}}$ & $4.40^{\mathrm{a}}$ & $4.65^{\mathrm{a}}$ & $4.43^{\mathrm{a}}$ & $4.81^{\mathrm{a}}$ \\
\hline Sphingomonadales & $0.98^{c}$ & $5.58^{\mathrm{ab}}$ & $6.84^{\mathrm{a}}$ & $5.07^{\mathrm{ab}}$ & $4.64^{b}$ & $3.72^{\mathrm{b}}$ & $4.54^{\mathrm{b}}$ & $4.50^{\mathrm{b}}$ & $4.27^{\mathrm{b}}$ & $3.74^{b}$ \\
\hline Xanthomonadales & $1.34^{d}$ & $5.48^{\mathrm{b}}$ & $7.19^{\mathrm{a}}$ & $4.68^{b c}$ & $3.16^{\mathrm{c}}$ & $2.98^{\mathrm{cd}}$ & $3.86^{\mathrm{bc}}$ & $3.38^{c}$ & $4.43^{\mathrm{bc}}$ & $3.48^{\mathrm{C}} \mathrm{r}-\mathrm{c}$ \\
\hline Burkholderiales & $1.74^{\mathrm{e}}$ & $4.87^{\mathrm{a}}$ & $3.98^{\mathrm{abc}}$ & $4.27^{\mathrm{ab}}$ & $3.12^{\mathrm{bcd}}$ & $2.04^{\mathrm{de}}$ & $2.15^{\mathrm{de}}$ & $3.02^{\mathrm{cd}}$ & $1.38^{\mathrm{e}}$ & $1.68^{\mathrm{e}}$ \\
\hline Rhodospirillales & $0.77^{c}$ & $2.71^{b}$ & $2.77^{b}$ & $3.03^{b}$ & $3.64^{\mathrm{ab}}$ & $3.28^{\mathrm{ab}}$ & $3.44^{\mathrm{ab}}$ & $3.51^{\mathrm{ab}}$ & $3.41^{\mathrm{ab}}$ & $4.37^{\mathrm{a}}$ \\
\hline
\end{tabular}

Values followed by different letters are considered significantly different $(p<0.05)$ according to Duncan's multiple comparison test. INI initial soil without treatment, CK1 and CK5 no fertilizer for 1 and 5 years, respectively, M1 and M5 1 year and 5 years of mineral fertilizer, O1 and O5 1 year and 5 years of organic fertilizer, MO1 and MO5 1 year and 5 years of combined of inorganic and organic fertilization, FS normal farmland soil without land subsidence

Relationships between soil chemical properties, bacterial community structures, and maize yields

Statistical analysis was utilized to evaluate the correlation among soil properties, microbial structures, and maize yield. The data represented in Table 4 showed $\mathrm{pH}$ had no significant correlation with microbial abundance and diversity. The significant positive correlations between the soil properties (AP, AK, AN, and $\mathrm{MBC}$ ) and bacterial diversity based on the Chao $1(r=0.559-0.838$, $p<0.01)$ ACE $(r=0.562-0.841, p<0.01)$, and Shannon indices $(r=0.558-0.722, p<0.01)$. In addition, soil MBC showed significant positive correlations with AP, $\mathrm{AK}$, and AN $(p<0.01)$. Maize yields were significantly correlated with both the bacterial diversity $(p<0.01)$ and the soil chemical properties (AP, AK, AN, and $\mathrm{MBC}, p<0.01$ ), suggesting that the increased crop yield of restored areas resulted from a recovering soil ecosystem with fertilization treatments. In addition, the correlation analysis between soil environmental factors and microbial composition was shown in Fig. 4. Proteobacteria was positively correlated with AK $(p<0.05)$. Firmicutes, Nitrospirae, and Euryaychaeota were negatively correlated with AN and AK $(p<0.01)$, while Bacteroidetes was positively correlated $(p<0.05$ and $p<0.01)$. Moreover, Actinobacteria and Planctomycetes were positively correlated with AN, AP, and AK. Except for Planctomycetes and GAL15, no other bacteria were significantly correlated with $\mathrm{pH}$.

Redundancy analysis (RDA) was conducted to evaluate the effects of soil characteristics on microbial composition (Fig. 5). Four soil indices accounted for $90.23 \%$ of the variation, among which the first axis and the second axis accounted for $70.52 \%$ and $19.71 \%$. The bacterial populations in the 1-year groups (CK1, M1, O1, and MO1) and INI were plotted on the positive side of axis 2, while the 5-year groups (CK5, M5, O5, and MO5) and FS bacterial populations were plotted on the negative side of axis 2 . The microbial composition

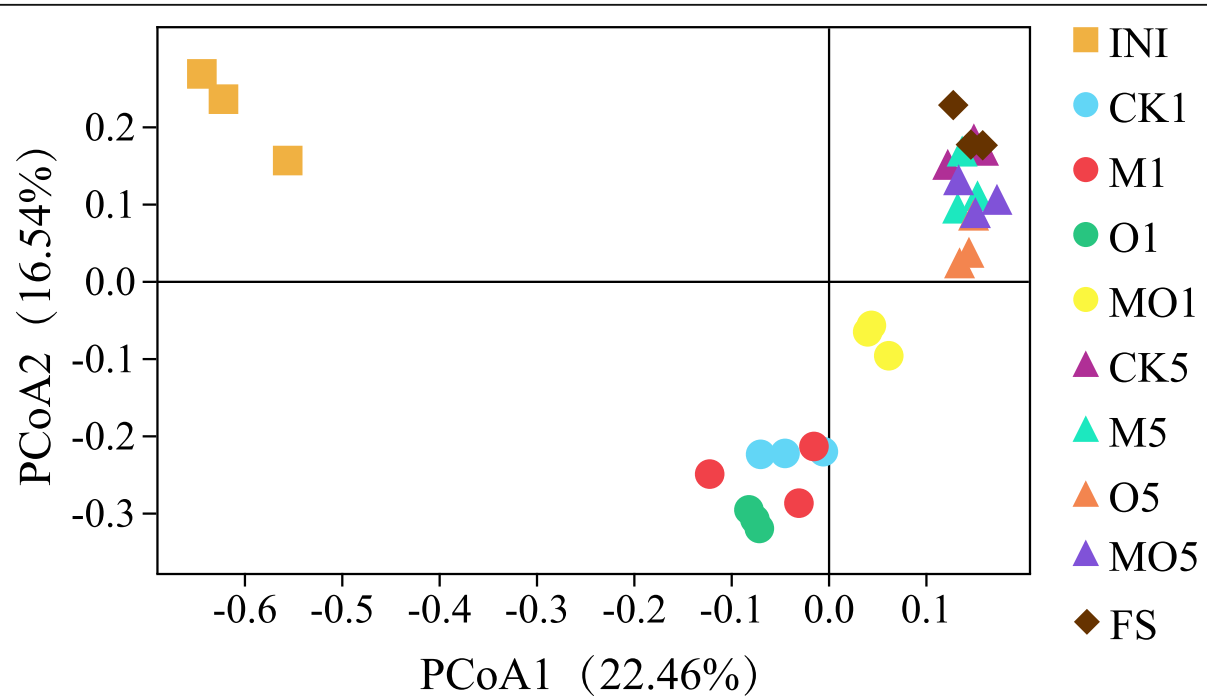

Fig. 3 Principal coordinates analysis (PCOA) used for evaluating the general microbial community compositions from the reclaimed site, unreclaimed soil (INI), and normal farmland soil (FS) 
Table 4 Correlation between microbial diversity parameters, soil properties, and maize yield

\begin{tabular}{lllllll}
\hline & $\mathrm{pH}$ & $\mathrm{AP}(\mathrm{mg} / \mathrm{kg})$ & $\mathrm{AK}(\mathrm{mg} / \mathrm{kg})$ & $\mathrm{AN}(\mathrm{mg} / \mathrm{kg})$ & $\mathrm{MBC}(\mathrm{mg} / \mathrm{kg})$ & Maize yield $(\mathrm{kg} / \mathrm{ha})$ \\
\hline Chao 1 & - & $0.559^{* *}$ & $0.838^{* *}$ & $0.793^{* *}$ & $0.584^{* *}$ & $0.703^{* *}$ \\
ACE & - & $0.562^{* *}$ & $0.841^{* *}$ & $0.798^{* *}$ & $0.584^{* *}$ & $0.706^{* *}$ \\
Shannon & - & $0.558^{* *}$ & $0.712^{* *}$ & $0.722^{* *}$ & $0.605^{* *}$ & $0.641^{* *}$ \\
MBC $(\mathrm{mg} / \mathrm{kg})$ & - & $0.978^{* *}$ & $0.759^{* *}$ & $0.879^{* *}$ & 1 & $0.967^{* *}$ \\
Maize yield $(\mathrm{kg} / \mathrm{ha})$ & - & $0.961^{* *}$ & $0.825^{* *}$ & $0.943^{* *}$ & $0.967^{* *}$ & 1 \\
\hline
\end{tabular}

The relationships among different parameters were analyzed using Pearson correlation analysis. ${ }^{*} p<0.05$ and ${ }^{* *} p<0.01$ were all considered statistically significant. Insignificant correlations were omitted. $A P$ available phosphorus, $A K$ available potassium, $A N$ alkali-hydrolyzable nitrogen, $M B C$ microbial biomass carbon

of the 5-year reclamation sites at the family level demonstrated an association with higher AP, AK, and AN content.

\section{Discussion}

This study was conducted to evaluate the recovery and responses of soil's bacterial communities after different reclamation treatments in a mining area. Results were based on high-throughput pyrosequencing of $16 \mathrm{~S}$ rDNA. In the present study, a total of $1,938,561$ sequences were classified. This number far exceeds those of other $16 \mathrm{~S}$ rDNA-sequencing studies of soil microbial diversity in

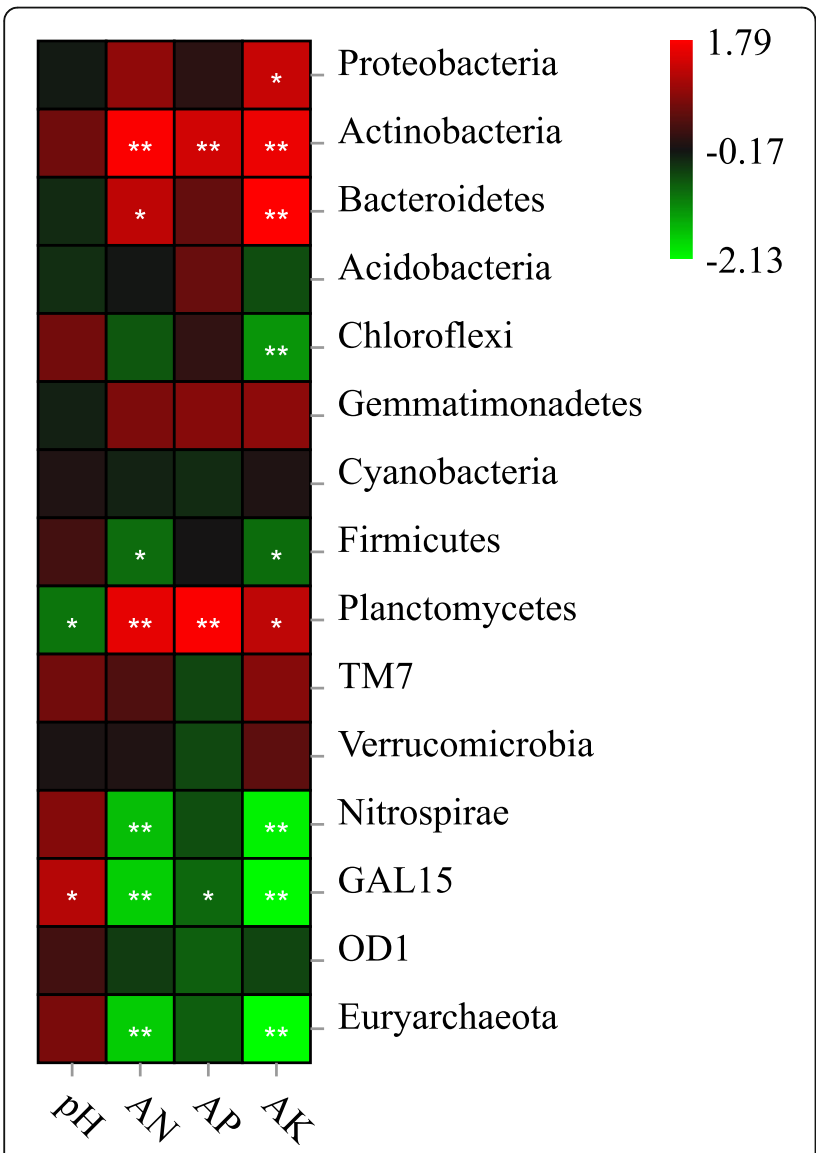

Fig. 4 Heatmap showing the correlation between the soil factors $(\mathrm{pH}, \mathrm{AN}, \mathrm{AP}$, and $\mathrm{AK})$ and the top 15 bacterial at the phylum level restoration areas (Bastida et al. 2013; Chen et al. 2013; Li et al. 2014c).

Our results indicated that the dominant bacteria in all of the treatments were Proteobacteria, Actinobacteria, Bacteroidetes, Acidobacteria, Chloroflexi, Gemmatimonadetes, and Firmicutes at the phylum level (Fig. 2a). Similar bacteria profiles were also shown in a uranium mining area (Rastogi et al. 2010) and in soil applied with bioorganic fertilizer (Chen et al. 2012), which suggests that the dominant bacteria are conserved across a range of disturbed sites and treatments. In this study, the relative abundances of Proteobacteria and Bacteroidetes increased after reclamation, while a decreasing trend was shown in Acidobacteria and Chloroflexi (Fig. 2b). The relative abundances of Proteobacteria and Actinobacteria were considerably increased after 5 years of reclamation, making them the most common and ubiquitous groups in all soil samples. The increased trend of Proteobacteria and Actinobacteria following soil reclamation suggested that they might play important roles in the process of soil reclamation, which is consistent with previous studies regarding forest ecosystem soil restoration (Banning et al. 2011). Actinobacteria play a major role in improving agricultural soil quality (Francioli et al. 2016). In our study, the abundance of Actinobacteria in the soil treated with organic fertilizer or organic combined chemical fertilizer was higher than in soil treated with chemical fertilizer alone (Table S2). The organic manure can supply more available $\mathrm{C}$ and $\mathrm{N}$ sources than chemical fertilizer, and increase soil aggregation and water-holding capacity (Wang and Yang 2003); these greatly promote the growth of Actinobacteria. The abundance of Proteobacteria increased rapidly (from 20.40 to $38.17 \%$ ) after the first year of reclamation; however, it was a significantly decrease after 5 years of reclamation and reached the same abundance as FS (Fig. 2b). Ai et al. (2015) reported Proteobacteria has the largest proportion in bacterial community composition from quantity, which has been proven in the present study. We also found that several Proteobacteria subgroups in soils, such as Rhizobiales, Myxococcales, Rhodospirillales, 


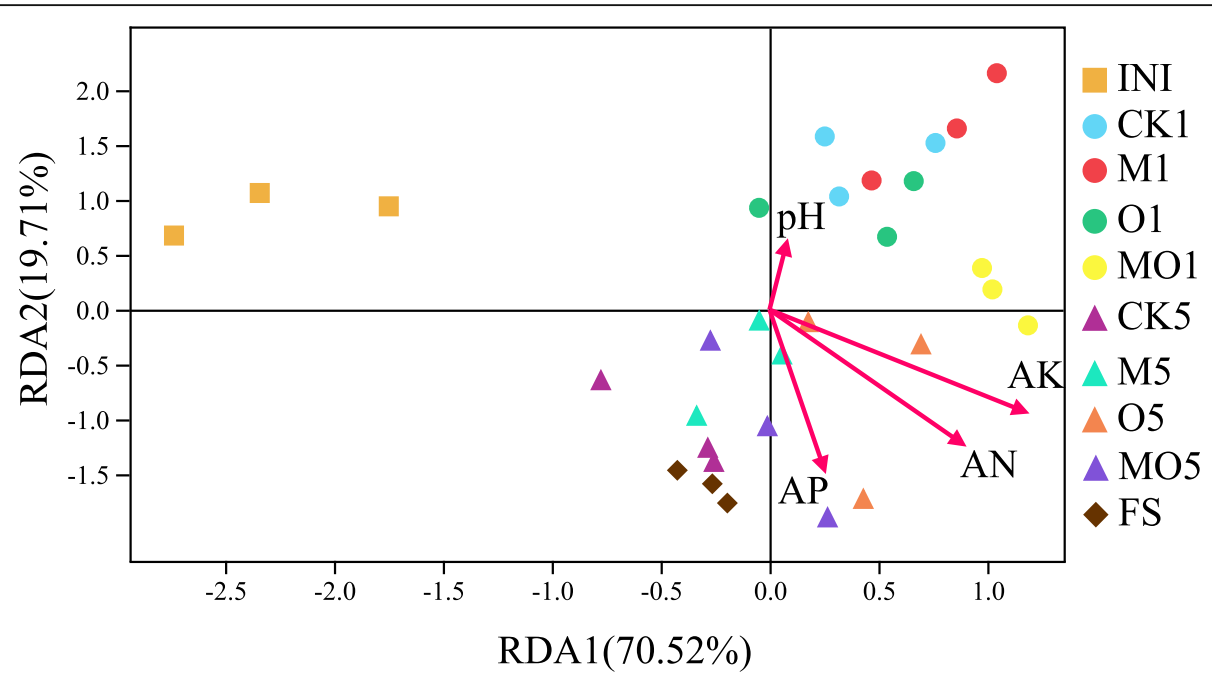

Fig. 5 Redundancy analysis (RDA) showing relationships between microbial communities and selected soil properties. The environmental factors, various fertilization, and reclamation time are indicated by red arrows, different colors, and shapes, respectively

Xanthomonadales, Burkholderiales, and Sphingomonadales increased after the restoration (Table 3). Rhizobiales and Burkholderiales participate in nitrogen-fixation in soil (Erlacher et al. 2015).The abundance of Rhizobiales significantly increased from $1.86 \%$ (INI) to $5.42 \%$ after reclamation, it should be associated with increased concentrations of $\mathrm{AN}$ and AK (Fig. S2). The abundance of Burkholderiales increased rapidly after 1 year of reclamation and decreased significantly to the same abundance as in FS after 5 years. They were found to participate in pentachlorophenol biodegradation in iron-reducing paddy soil and as a degrader of 3-hydroxybutyrate-co3-hydroxyhexanoate (PHBH) films in biofilm functions (Tong et al. 2015; Morohoshi et al. 2018).The abundance of Rhodospirillales in the 5-year group was higher than in the 1-year group. These organisms have extreme metabolic versatility encompassing photoheterotrophic, chemoorganotrophic, and photoautotrophic lifestyles, and could potentially adapt well to extremely oligotrophic areas and benefit from higher productivity (King et al. 2010; Ding et al. 2018). These findings indicate Proteobacteria plays important roles in restoring ecosystems.

According to our results, the microbial soil community structure was distinctly altered by reclamation treatments (Table 2), which is consistent with previous studies on alterations to soil microbial diversity in mining-recovery soils (Dangi et al. 2012; Li et al. 2014b; Singh et al. 2004). The microbial diversity in all reclaimed treatments (M1, $\mathrm{O} 1, \mathrm{MO} 1, \mathrm{M} 5, \mathrm{O} 5$, and MO5) was higher than that of the initial untreated site (INI). In addition, the microbial composition in the 5-year groups was more similar to the FS group than in the 1-year groups were (Fig. 2). Moreover, there were significant differences in the abundance of some bacteria such as Proteobacteria, Actinobacteria, and Bacteroidetes between chemical and organic fertilizer treatments (Table S2). These data implied that both fertilizer treatment and the reclamation time were important driving factors affecting soil microbial diversity and construction, and the longer the reclamation is, the more effectively the soil mends.

It is well known that soil ecosystem functions are driven by interactions between microbial communities and chemical properties, and the alteration of these interactions may influence microbial communities and diversity (Singh et al. 2004). A growing number of studies have presented evidence that chemical properties influence shifts in soil microbial communities and diversity (García-Orenes et al. 2013; Liang et al. 2012; Zornoza et al. 2015). In our study, the soil properties (AP, AK, $\mathrm{AN}$, and $\mathrm{MBC}$ contents) were found to be improved after long-term reclamation with fertilizations. Organic fertilizer treatment is suggested to be the most effective method for restoring soil properties over a long-term period. In addition, the combination of organic and inorganic fertilization could achieve a similar effect on soil properties in reclaimed areas. More importantly, the soil properties and bacterial community structure exhibited a positive correlation supported by the Chao 1, ACE, and Shannon indices (Table 4) and RDA analysis (Fig. 5). Thus, the changes to bacterial communities and diversities may be attributable to changes in the soil properties.

Previous studies have demonstrated that re-vegetation plays a significant role in the protection of soil from erosion and in increasing in the accumulation of soil nutrients in mining lands (Conesa et al. 2007; Sheoran et al. 2010). Furthermore, re-vegetation in reclaimed 
areas affects soil fertility by producing abundant decomposable nutrients ( $\mathrm{Li}$ et al. 2014c). Organic substances provided by plant roots play important roles in stabilizing soil aggregates by providing energy for microbes (Six et al. 2004). The maize yields were increased significantly under all treatments of 1-year and 5-year treatments, which showed results consistent with previous studies. For example, maize yields in the 5-year treatment plots were approximately $5870 \mathrm{~kg} \mathrm{ha}^{-1}$, which is close to the average maize yield in China during 2012 (National Bureau of Statistics of China, 2012). However, the maize yields and soil properties (AP, AN, and $\mathrm{MBC}$ ) in the 5-year groups were still significantly different compared to those in the FS group, indicating that the soil fertility can be further improved after 5 -year reclamation.

\section{Conclusions}

The soil fertility and microbial community were seriously affected by the coal mining. Fertilization can effectively improve soil fertility and restore microbial diversity in the subsided area, especially after five successive years of treatment. We conclude that soil AN, AK, and AP were the main environmental factors affecting the soil microbial communities and diversity, rather than the $\mathrm{pH}$. Proteobacteria and Actinobacteria play important roles in the process of soil reclamation. The maize yields achieved the approximate average in China with the 5-year treatment groups, suggesting that it could take about 5 years for the subsided soil in the coalmining area to improve its productivity. Moreover, our study suggested that fertilizer application and reclamation time were the important driving factors for improving soil microbial diversity and soil fertility. Therefore, fertilization of reclaimed soil in subsided areas has the potential to be an effective strategy for soil reuses worldwide.

\section{Supplementary information}

Supplementary information accompanies this paper at https://doi.org/10. 1186/s13213-020-01589-2.

Additional file 1: Figure S1. Shannon rarefaction curves showing the microbial diversity levels across different samples from initial soil (INI), reclamation sites (CK1, M1, O1, MO1, CK5, M5, O5 and MO5) and normal farmland soil (FS).

Additional file 2: Figure S2. Heatmap showing the correlation between the soil factors ( $\mathrm{pH}, \mathrm{AN}, \mathrm{AP}$ and $\mathrm{AK})$ and the top 20 bacterial at the Order level.

Additional file 3: Table S1. Soil properties and maize yields under different fertilizer treatments. Table S2. Relative abundance of phylogenetic phylum at each experimental site.

\section{Research involving human participants and/or animals}

This article does not contain any studies with human participants performed by any of the authors.

\section{Authors' contributions}

$\mathrm{JH}$ and $\mathrm{HM}$ conceived of and designed the experiments. $\mathrm{YC}$ and $\mathrm{BZ}$ performed the experiments and wrote the paper. XW analyzed the data. JZ and $L L$ contributed reagents/materials/analysis tools. The authors read and approved of the final manuscript.

\section{Funding}

This work was supported by the National Natural Science Foundation of China (U1710255 and 21272257), Natural Science Foundation of Shanxi Province (201901D111218), and Shanxi Province Foundation for Returnees (2016-072).

\section{Ethics approval and consent to participate}

Informed consent was obtained from all individual participants included in the study.

\section{Competing interests}

The authors declare that they have no conflicts of interest.

Received: 7 April 2020 Accepted: 3 July 2020

Published online: 23 July 2020

\section{References}

Ai C, Liang G, Sun J, Wang X, He P, Zhou W, He X (2015) Reduced dependence of rhizosphere microbiome on plant-derived carbon in 32-year long-term inorganic and organic fertilized soils. Soil Biol Biochem 80:70-78

Anderson TH (2003) Microbial eco-physiological indicators to asses soil quality. Agriculture Ecosystems and Environment 98:285-93.

Anderson JD, Ingram LJ, Stahl PD (2008) Influence of reclamation management practices on microbial biomass carbon and soil organic carbon accumulation in semiarid mined lands of Wyoming. Appl Soil Ecol 40:387-397

Banning NC, Gleeson DB, Grigg AH, Grant CD, Andersen GL, Brodie EL, Murphy DV (2011) Soil microbial community successional patterns during forest ecosystem restoration. Appl Environ Microbio 77:6158-6164

Bartram AK, Lynch MDJ, Stearns JC, Moreno-Hagelsieb G, Neufeld JD (2011) Generation of multimillion-sequence 165 rRNA gene libraries from complex microbial communities by assembling paired-end illumina reads. Appl Environ Microbiol 77:3846-3852

Bastida F, Hernández T, Albaladejo J, García C (2013) Phylogenetic and functional changes in the microbial community of long-term restored soils under semiarid climate. Soil Biol Biochem 65:12-21

Chen L, Huang X, Zhang F, Zhao D, Yang X, Shen Q (2012) Application of Trichoderma harzianum SQR-T037 bio-organic fertiliser significantly controls Fusarium wilt and affects the microbial communities of continuously cropped soil of cucumber. J Sci Food Agr 92:2465-2470

Chen L, Li J, Chen Y, Huang L, Hua Z, Hu M, Shu W (2013) Shifts in microbial community composition and function in the acidification of a lead/zinc mine tailings. Environ Microbiol 15:2431-2444

Colwell JD (1963) The estimation of the phosphorus fertilizer requirements of wheat in southern New South Wales by soil analysis. Aust J Exp Agr 3:190197

Conesa HM, García G, Faz Á, Arnaldos R (2007) Dynamics of metal tolerant plant communities' development in mine tailings from the Cartagena-La Unión Mining District (SE Spain) and their interest for further revegetation purposes. Chemosphere 68:1180-1185

Cox AE, Joern BC, Brouder SM, Gao D (1999) Plant-available potassium assessment with a modified sodium tetraphenylboron method journal paper no. 15627 of the Indiana Agric. Res. Program, West Lafayette. Soil Sci. Soc. Am. J 63:902-91

Cui J, Liu C, Li Z, Wang L, Chen X, Ye Z, Fang C (2012) Long-term changes in topsoil chemical properties under centuries of cultivation after reclamation of coastal wetlands in the Yangtze Estuary, China. Soil Till Res 123:50-60

Czarnes S, Hallett PD, Bengough AG, Young IM (2000) Root and microbial-derived mucilages affect soil structure and water transport. Eur I Soil Sci 51:435-443

Dangi SR, Stahl PD, Wick AF, Ingram LJ, Buyer JS (2012) Soil microbial community recovery in reclaimed soils on a surface coal mine site. Soil Sci. Soc. Am. J. 915-924.

Dimitriu PA, Prescott CE, Quideau SA, Grayston SJ (2010) Impact of reclamation of surface-mined boreal forest soils on microbial community composition and function. Soil Biol. Biochem 42:2289-2297 
Ding L, Su J, Sun G, Wu J, Wei W (2018) Increased microbial functional diversity under long-term organic and integrated fertilization in a paddy soil. Appl Microbiol Biotechnol 102:1969-1982

Erlacher A, Cernava T, Cardinale M, Soh J, Sensen CW, Grube M, Berg G (2015) Rhizobiales as functional and endosymbiontic members in the lichen symbiosis of Lobaria pulmonaria L. Front Microbiol 6:1-9

Falkowski PG, Fenchel T, Delong EF (2008) The microbial engines that drive earth's biogeochemical cycles. Science 320:1034-1039

Francioli D, Schulz E, Lentendu G, Wubet T, Buscot F, Reitz T (2016) Mineral vs. organic amendments: microbial community structure, activity and abundance of agriculturally relevant microbes are driven by long-term fertilization strategies. Front.Microbiol 7:1446

García-Orenes F, Morugán-Coronado A, Zornoza R, Scow K (2013) Changes in soil microbial community structure influenced by agricultural management practices in a Mediterranean agro-ecosystem. PLOS ONE 8:e80522

Hossain MN, Paul S, Hasan MM (2015) Environmental impacts of coal mine and thermal power plant to the surroundings of Barapukuria, Dinajpur, Bangladesh. Environ Monit Assess 187:1-11

King AJ, Freeman KR, McCormick KF, Lynch RC, Lozupone C, Knight R, Schmidt SK (2010) Biogeography and habitat modelling of high-alpine bacteria. Nature Communications 1(5):1-6

Kowalchuk GA, Stephen JR (2001) Ammonia-oxidizing bacteria: a model for molecular microbial ecology. Annu Rev Microbiol 55:485-529

Li J, Pu L, Zhu M, Zhang J, Li P, Dai X, Xu Y, Liu L (2014a) Evolution of soil properties following reclamation in coastal areas: A review. Geoderma 226227:130-139

Li Y, Chen L, Wen H, Zhou T, Zhang T, Gao X (2014b) 454 pyrosequencing analysis of bacterial diversity revealed by a comparative study of soils from mining subsidence and reclamation areas. J Microbiol Biotechnol 24:313-323

Li Y, Wen H, Chen L, Yin T (2014c) Succession of bacterial community structure and diversity in soil along a chronosequence of reclamation and revegetation on coal mine spoils in China. PLoS ONE 9:e115024

Liang C, Jesus EdC, Duncan DS, Jackson RD, Tiedje JM, Balser TC (2012) Soil microbial communities under model biofuel cropping systems in southern Wisconsin, USA: Impact of crop species and soil properties. Appl Soil Ecol 54: 24-31

Morohoshi T, Oi T, Aiso H, Suzuki T, Okura T, Sato S (2018) Biofilm formation and degradation of commercially available biodegradable plastic films by bacterial consortiums in freshwater environments. Microbes Environ 33(3): 332-335

Muyzer G, de Waal EC, Uitterlinden AG (1993) Profiling of complex microbial populations by denaturing gradient gel electrophoresis analysis of polymerase chain reaction-amplified genes coding for 165 rRNA. Appl Environ Microbiol 59:695-700

Rastogi G, Osman S, Vaishampayan P, Andersen G, Stetler L, Sani R (2010) Microbial diversity in uranium mining-impacted soils as revealed by highdensity 165 microarray and clone library. Microb Ecol 59:94-108

Sheoran V, Sheoran A, Poonia P (2010) Soil reclamation of abandoned mine land by revegetation: a review. Int J Soil Sed Water 3:13

Singh BK, Millard P, Whiteley AS, Murrell JC (2004) Unravelling rhizosphere-microbial interactions: opportunities and limitations. Trends Microbiol 12:386-393

Six J, Bossuyt H, Degryze S, Denef K (2004) A history of research on the link between (micro)aggregates, soil biota, and soil organic matter dynamics. Soil Till Res 79:7-31

Song YN, Zhang FS, Marschner P, Fan FL, Gao HM, Bao XG, Sun JH, Li L (2007) Effect of intercropping on crop yield and chemical and microbiological properties in rhizosphere of wheat (Triticum aestivum L.), maize (Zea mays L. ), and faba bean (Vicia faba L.). Biol Fertil Soils 43:565-574

Tong H, Hu M, Li F, Chen M, Lv Y (2015) Burkholderiales participating in pentachlorophenol biodegradation in iron-reducing paddy soil as identified by stable isotope probing. Environ Sci Process Impacts 17(7):1282-1289

Tripathi N, Singh RS, Singh JS (2009) Impact of post-mining subsidence on nitrogen transformation in southern tropical dry deciduous forest. India Environ Res 109:258-266

Trumbore S (2006) Carbon respired by terrestrial ecosystems - recent progress and challenges. Global Change Biol 12:141-153

Vance ED, Brookes PC, Jenkinson DS (1987) An extraction method for measuring soil microbial biomass C. Soil Biol Biochem 19:703-707

Wang M, Yang C (2003) Type of fertilizer applied to a paddy-upland rotation affects selected soil quality attributes. Geoderma 114:93-108
Wang Y, Ji H, Gao C (2016) Differential responses of soil bacterial taxa to longterm $\mathrm{P}, \mathrm{N}$, and organic manure application. Journal of Soils and Sediments 16:1046-1058

Xiong Y, Xia H, Li Z, Cai X, Fu S (2008) Impacts of litter and understory removal on soil properties in a subtropical Acacia mangiumplantation in China. Plant Soil 304:179-188

Yi Q, Xie K, Sun P, Kim Y (2014) Characterization of phosphorus in the sedimentary environments of inundated agricultural soils around the Huainan Coal Mines, Anhui, China. Sci Total Environ 472:538-549

Zornoza R, Acosta JA, Martínez-Martínez S, Faz A, Bååth E (2015) Main factors controlling microbial community structure and function after reclamation of a tailing pond with aided phytostabilization. Geoderma 245-246:1-10

\section{Publisher's Note}

Springer Nature remains neutral with regard to jurisdictional claims in published maps and institutional affiliations.
Ready to submit your research? Choose BMC and benefit from:

- fast, convenient online submission

- thorough peer review by experienced researchers in your field

- rapid publication on acceptance

- support for research data, including large and complex data types

- gold Open Access which fosters wider collaboration and increased citations

- maximum visibility for your research: over $100 \mathrm{M}$ website views per year

At BMC, research is always in progress.

Learn more biomedcentral.com/submissions 